\title{
Pengujian Berbagai Dosis Pupuk Kandang Kambing untuk Pertumbuhan dan Produksi Jagung Manis Organik (Zea mays var. Saccharata Sturt)
}

\section{Growth and Production of Sweet Corn (Zea mays var. Saccharata Sturt.) with Various Rates of Goat Manure}

\author{
Bayu Aditya Sinuraya dan Maya Melati*
}

\author{
Departemen Agronomi dan Hortikultura, Fakultas Pertanian, Institut Pertanian Bogor \\ (Bogor Agricultural University), Jl. Meranti, Kampus IPB Darmaga, Bogor 16680, Indonesia \\ Telp. \& Faks.62-251-8629353 e-mail agrohort@apps.ipb.ac.id \\ *Penulis Korespondensi : mayamelati14@gmail.com
}

Disetujui : 16 Mei 2018 / Published Online 2 Januari 2019

\begin{abstract}
Organic farming increasingly draws attention to change common life that use non-natural chemicals in the cultivation of agriculture into a healthy-eco-friendly living. Manure in organic farming is the main source of nutrients in its cultivation. Organic manure has a smaller nutrient content than chemical fertilizers, therefore the need for manure will be enormous in the cultivation of organic farming. This research aims to study and gain the best dosage of manure for growth and production of sweet corn (Zea mays var. Saccharata Sturt). This research was conducted in April until July 2017 located at Organic Experimental Field of IPB, Cikarawang, Dramaga, Bogor. This experiment used a complete randomized block design (RCBD) with single factor namely dosage of goat manure with 4 treatment levels $(0,10,20$ and 30 ton ha $\mathrm{c}^{-1}$ ) and 3 replications. There were 12 experimental units. The results showed that the treatment of manure dose significantly affected the growth of organic sweet corn. The dose of 30 tons ha ${ }^{-1}$ significantly increased plant height and number of leaves. The treatment of manure dose did not significantly affect the yield and yield components of organic sweet corn.
\end{abstract}

Keywords: dextrose brix, chlorophyll, goat manure nutrient, leaf colour

\begin{abstract}
ABSTRAK
Pertanian organik semakin menarik perhatian untuk mengubah pola hidup lama yang menggunakan bahan kimia non-alami dalam budidaya pertanian menjadi pola hidup sehat ramah lingkungan. Pupuk kandang pada pertanian organik merupakan sumber utama unsur hara dalam budidayanya. Pupuk organik memiliki kandungan unsur hara yang lebih kecil dibandingkan pupuk anorganik, oleh sebab itu kebutuhan pupuk kandang akan sangat besar dalam budidaya pertanian organik. Penelitian ini bertujuan unutk mempelajari dan mendapatkan pengaruh dosis pupuk kandang terbaik terhadap pertumbuhan dan produksi jagung manis (Zea mays var. Saccharata Sturt). Penelitian dilaksanakan pada bulan April sampai Juli 2017 bertempat di Kebun Percobaan Organik IPB Cikarawang, Dramaga, Bogor. Percobaan ini menggunakan rancangan kelompok lengkap teracak (RKLT) dengan faktor tunggal yaitu dosis pupuk kandang kambing dengan 4 taraf perlakuan $\left(0,10,20\right.$ dan 30 ton ha $\left.{ }^{-1}\right)$ dan masing-masing taraf terdapat 3 ulangan sehingga terdapat 12 satuan percobaan. Hasil penelitian menunjukkan bahwa perlakuan dosis pupuk kandang berpengaruh nyata terhadap pertumbuhan jagung manis organik. Perlakuan dosis pupuk kandang 30 ton ha ${ }^{-1}$ nyata meningkatkan tinggi tanaman dan jumlah daun. Perlakuan dosis pupuk kandang tidak berpengaruh nyata terhadap produksi dan komponen produksi jagung manis organik.
\end{abstract}

Kata kunci: derajat kemanisan, hara pupuk kandang kambing, klorofil, warna daun 


\section{PENDAHULUAN}

Jagung manis merupakan sayuran yang baik untuk memenuhi pola hidup sehat, dan cukup populer di masyarakat indonesia. Kandungan zat gizi jagung manis tiap $100 \mathrm{~g}$ bahan adalah Energi (kal) 96.0, Protein (g) 3.5, Lemak (g) 1.0, Karbohidrat (g) 22.8, Kalsium (mg) 3.0, Fosfor (mg) 111, Besi (mg) 0.7, Vitamin A (SI) 400, Vitamin B (mg) 0.15, Vitamin C (mg) 12.0, dan Air (g) 72.7 (Iskandar, 2007). Selain dijadikan sebagai sayuran, jagung juga dapat dibakar dan direbus. Permintaan pasar terhadap jagung manis terus meningkat seiring dengan munculnya pasar swalayan. Menurut Seprita dan Surtinah (2012) faktor yang dapat merangsang para petani untuk mengembangkan usaha tanaman jagung manis adalah kebutuhan yang meningkat dan harga yang tinggi. Untuk memenuhi kebutuhan pasar tersebut petani cenderung masih menggunakan pupuk anorganik.

Pertanian organik menjadi sangat menarik perhatian untuk mengubah pola hidup lama yang menggunakan bahan kimia non-alami dalam budidaya pertanian menjadi pola hidup sehat ramah lingkungan. Salah satu langkah untuk itu ialah dengan mengkonsumsi produk organik sehat dan bergizi tinggi yang dapat diproduksi dengan metode pertanian organik (Mayrowani, 2012), tak terkecuali sayuran organik. Dampak produk organik terhadap kesehatan merupakan motivasi utama konsumen dalam memilih produk organik (Huber et al., 2011). Budidaya tanaman secara organik tidak hanya sebatas meniadakan penggunaan bahan sintetis, tetapi juga menuntut agar lahan yang digunakan tidak tercemar serta mempunyai aksesibilitas yang baik dan berkesinambungan. Pemberian pupuk organik ke dalam tanah dapat mempengaruhi dan memperbaiki sifat-sifat tanah baik fisika, kimia maupun biologi tanah (Pranata, 2010).

Pupuk organik berfungsi untuk meminimalisir efek residu yang disebabkan oleh pupuk anorganik dan mampu menambah unsur hara makro dan mikro serta memperbaiki sifat kimia, biologi, dan fisika tanah. Menurut Lingga dan Marsono (2006) pupuk organik dapat berasal dari pelapukan sisa tanaman, hewan dan manusia. Salah satu sumber pupuk organik berasal dari kotoran ternak kambing. Kotoran kambing relatif mudah diperoleh sebagai sumber utama unsur hara dalam budidaya organik. Kebutuhan pupuk kandang sangat besar karena kandungan haranya yang rendah. Menurut Hartatik dan Widowati (2006) pupuk kandang kambing memiliki kandungan hara $0.70 \% \mathrm{~N}, 0.40 \% \mathrm{P}_{2} \mathrm{O}_{5}, 0.25 \%$ $\mathrm{K}_{2} \mathrm{O}, \mathrm{C} / \mathrm{N}$ 20-25, dan bahan organik $31 \%$.
Informasi tentang kebutuhan pupuk organik untuk budidaya jagung manis secara organik masih terbatas, oleh karena itu penelitian ini dilakukan untuk mempelajari respon tanaman jagung manis terhadap perbedaan dosis pupuk kandang kambing.

\section{BAHAN DAN METODE}

Penelitian ini dilaksanakan di Kebun Percobaan IPB Cikarawang, Dramaga, Bogor. Laboratorium Agronomi dan Hortikultura, Fakultas Pertanian, Institut Pertanian Bogor. Penelitian ini dilaksanakan pada bulan April sampai dengan Juli 2017. Bahan yang digunakan adalah benih jagung manis (Zea mays var. saccharata Sturt.) varietas SD-3, pupuk kandang kambing. Peralatan yang digunakan antara lain alat budidaya pertanian yang umum digunakan, oven, ajir bambu, tiang bambu, abu sekam.

Penelitian ini menggunakan Rancangan Kelompok Lengkap Teracak (RKLT) dengan 3 ulangan. Perlakuan terdiri dari 1 faktor yaitu, dosis pupuk kandang kambing dengan 4 taraf yaitu $0,10,20$, dan 30 ton ha ${ }^{-1}$. Sehingga terdapat 12 satuan percobaan.

Persiapan lahan percobaan diawali dengan membersihkan gulma dari lahan kemudian pengapuran dengan dosis 2 ton ha $^{-1}$ serta pemberian abu sekam dengan dosis 1 ton $\mathrm{ha}^{-1}$ yang dilaksanakan 2 minggu sebelum tanam. Lahan dibagi menjadi 12 petakan dengan masingmasing petakan $4 \mathrm{~m} \times 4.5 \mathrm{~m}$. Pengambilan contoh tanah untuk kesesuaian percobaan dilakukan sebelum pengolahan lahan. Pupuk kandang diaplikasikan 2 minggu sebelum penanaman tanaman jagung manis di lahan. Pemupukan selanjutnya dilakukan pada 3 MST. Pupuk kandang ditaburkan melalui alur yang dibuat di sekeliling tanaman dengan jarak $20 \mathrm{~cm}$. Pupuk diaplikasikan secara bertahap dengan dosis masing-masing $1 / 2$ dosis perlakuan pada 2 MST, selanjutnya $1 \frac{2}{2}$ pada 3 MST.

Penanaman dilakukan dengan menggunakan jarak tanam $75 \mathrm{~cm} \mathrm{x} 40 \mathrm{~cm}$, dengan penanaman 2 benih jagung setiap lubang tanam. Kegiatan pemeliharaan meliputi penyulaman bibit yang dilakukan pada 1 MST. Penyulaman dilakukan pada tanaman kurang sehat pertumbuhannya dan tanaman yang mati.

Pengendalian hama dan penyakit pada jagung dilakukan dengan bahan organik berupa penyemprotan larutan daun sirih sesuai anjuran, penyiangan gulma sesuai dengan kondisi lahan. Tanaman yang terserang penyakit bulai dicabut. Pemanenan dilakukan setelah tanaman berumur 60-70 hari setelah tanam. Peubah yang diamati 
pada percobaan ini adalah tinggi tanaman, jumlah daun, diameter batang, warna daun, analisis klorofil $(\mathrm{a}+\mathrm{b})$, bobot tongkol berkelobot, bobot tongkol tanpa kelobot, ukuran tongkol, derajat manis, bobot tongkol per petak, bobot tongkol layak pasar per petak.

\section{HASIL DAN PEMBAHASAN}

\section{Kondisi Umum}

Pengambilan sampel tanah untuk di analisis dilakukan di awal saat sebelum penelitian dimulai, pengambilan dilakukan secara komposit. Kondisi tanah pada lokasi percobaan dicantumkan pada Tabel 1.

Tabel 1. Hasil analisis tanah awal.

\begin{tabular}{lrcl}
\hline Karakter & Nilai & Satuan & \multicolumn{1}{c}{ Kriteria* } \\
\hline $\mathrm{pH}\left(\mathrm{H}_{2} \mathrm{O}\right)$ & 6.46 & & Agak masam \\
$\mathrm{C}$-Organik & 1.62 & $\%$ & Rendah \\
$\mathrm{N}$ Total & 0.18 & $\%$ & Rendah \\
$\mathrm{P}_{2} \mathrm{O}_{5}$ & 123.98 & $\mathrm{mg} / 100 \mathrm{~g}$ & Sangat tinggi \\
$\mathrm{K}_{2} \mathrm{O}$ & 25.87 & $\mathrm{Mg} / 100 \mathrm{~g}$ & Sedang \\
\hline
\end{tabular}

Keterangan: *Balai Penelitian Tanah (2009)

Data BMKG (2017) menunjukan kondisi iklim di lahan meliputi rata-rata bulanan curah hujan dari bulan April-Juli 2017 yaitu $350.9 \mathrm{~mm}$ bulan $^{-1}$. Curah hujan tertinggi pada bulan Juli sebesar $401.0 \mathrm{~mm}^{\text {bulan }}{ }^{-1}$ dan terendah pada bulan Mei sebesar $283.9 \mathrm{~mm} \mathrm{bulan}^{-1}$ (Tabel 2). Analisis hara pupuk organik kandang kambing disajikan pada Tabel 3.

Tabel 2. Kondisi cuaca selama percobaan.

\begin{tabular}{ccc}
\hline Bulan & $\begin{array}{c}\text { Temperatur } \\
\left({ }^{\circ} \mathrm{C}\right)\end{array}$ & $\begin{array}{c}\text { Curah Hujan } \\
(\mathrm{mm} / \mathrm{bln})\end{array}$ \\
\hline April & 26.1 & 283.9 \\
Mei & 26.4 & 319.4 \\
Juni & 26.3 & 399.6 \\
Juli & 26.0 & 401.0 \\
\hline Rata-Rata & 26.2 & 350.9 \\
\hline Keterangan: & Badan Meteorologi & Klimatologi dan \\
& \multicolumn{3}{l}{}
\end{tabular}

Tabel 3. Hasil analisis kandungan hara pupuk kandang

\begin{tabular}{lc}
\hline Karakter & Nilai $(\%)$ \\
\hline $\mathrm{pH}$ & 8.31 \\
$\mathrm{~N}$ total & 1.70 \\
$\mathrm{C}$-organik & 14.80 \\
$\mathrm{P}_{2} \mathrm{O}_{5}$ & 0.65 \\
$\mathrm{~K}_{2} \mathrm{O}$ & 6.52 \\
$\mathrm{C} / \mathrm{N}$ & 8.70 \\
\hline
\end{tabular}

\section{Pengaruh Dosis Pupuk Kandang Kambing terhadap Komponen Pertumbuhan Tanaman}

\section{Tinggi Tanaman}

Tanaman jagung yang diberi aplikasi pupuk kandang lebih tinggi dibandingkan tanaman yang tidak diberi aplikasi. Berdasarkan Tabel 4 pertambahan tinggi tanaman pada 3-6 MST dengan pemberian dosis 30, 20, 10 ton ha ${ }^{-1}$ dan tanpa perlakuan berturut-turut sebesar $173 \mathrm{~cm}$, $185.3 \mathrm{~cm}, 165.9 \mathrm{~cm}$, dan $143.5 \mathrm{~cm}$. Perlakuan dosis pupuk kandang 20 ton $\mathrm{ha}^{-1}$ menyebabkan pertambahan tinggi tanaman selama 3-6 MST yang paling besar dibandingkan dengan tanpa perlakuan yaitu $185.30 \mathrm{~cm}$.

Perlakuan dosis pupuk kandang sebesar 30 ton $\mathrm{ha}^{-1}$ memberikan pengaruh nyata terhadap tinggi tanaman jagung dan berbeda nyata terhadap dosis $0,10,20$ ton $\mathrm{ha}^{-1}$ pada umur 5 MST. Perlakuan dosis 30 ton $\mathrm{ha}^{-1}$ pada $5 \mathrm{MST}$ mengalami kenaikan sebesar 9.04\% dari tinggi tanaman pada perlakuan kontrol.

\section{Jumlah Daun}

Perlakuan dosis pupuk kandang pada 30 ton $\mathrm{ha}^{-1}, 20$ ton $\mathrm{ha}^{-1}, 10$ ton $\mathrm{ha}^{-1}$ dan tanpa perlakuan berturut-turut mengalami pertambahan jumlah daun pada 3-6 MST berturut-turut sebesar 5.7, 6.3, 6.1, dan 5.5. Berdasarkan data pada Tabel 5 pemberian dosis pupuk kandang berpengaruh nyata pada 4 dan 5 MST. Perlakuan dosis pupuk kandang 30 ton $\mathrm{ha}^{-1}$ pada 4 dan 5 MST menyebabkan jumlah daun berbeda nyata dengan tanpa perlakuan (kontrol). Pertambahan jumlah daun dengan dosis 30 ton $\mathrm{ha}^{-1}$ berturut-turut sebesar $8.57 \%$ dan $19.76 \%$ pada 4 dan 5 MST.

Tabel 4. Rata-rata tinggi tanaman dan pertambahan tinggi jagung (cm) berdasarkan dosis pupuk kandang

\begin{tabular}{lcccccc}
\hline \multirow{2}{*}{ Dosis Pupuk Kandang $\left(\right.$ ton ha $\left.^{-1}\right)$} & \multicolumn{4}{c}{ Umur Tanaman (MST) } & \multirow{2}{*}{ Pertambahan Tinggi Tanaman 3-6 MST } \\
\cline { 2 - 6 } & 3 & 4 & 5 & 6 & 143.50 \\
0 & 48.23 & 96.07 & 148.87 & $\mathrm{~b}$ & 191.73 & 165.90 \\
10 & 33.57 & 88.87 & 149.87 & $\mathrm{~b}$ & 199.47 & 185.30 \\
20 & 31.63 & 93.40 & 150.40 & $\mathrm{~b}$ & 216.93 & 173.00 \\
\hline 0 & 42.27 & 99.93 & 162.33 & $\mathrm{a}$ & 215.27 & \\
\hline
\end{tabular}

Keterangan: Angka yang diikuti huruf berbeda pada kolom yang sama berbeda nyata berdasarkan hasil Duncan's multiple range test (DMRT) pada taraf $\alpha=10 \%$, MST: minggu setelah tanam. 


\section{Diameter Batang}

Data pada Tabel 6 menunjukkan dosis pupuk kandang tidak berpengaruh nyata terhadap peubah pengamatan diameter batang jagung, namun menunjukkan adanya pertambahan diameter batang pada setiap minggunya. Pertambahan diameter batang pada 3-6 MST pada perlakuan dosis pupuk 30 ton ha ${ }^{-1}, 20$ ton ha ${ }^{-1}, 10$ ton $\mathrm{ha}^{-1}$, dan tanpa perlakuan berturut-turut sebesar 16.74, 14.67, 14.45, dan 14.04. Perlakuan dosis pupuk kandang 30 ton ha ${ }^{-1}$ memiliki pertambahan diameter batang pada 3-6 MST yang paling besar dibandingkan dengan tanpa perlakuan yaitu $16.74 \mathrm{~mm}$ namun tidak berbeda nyata.

\section{Pengaruh Dosis Pupuk Kandang terhadap Komponen Produksi Tanaman}

Berdasarkan data pada Tabel 7 dosis pupuk kandang tidak menunjukkan pengaruh yang nyata terhadap peubah jumlah tanaman petak bersih, jumlah tongkol petak bersih, bobot tongkol petak bersih, dan bobot tongkol layak pasar.

Data Tabel 8 menunjukkan pengaruh yang tidak nyata dari dosis pupuk kandang terhadap peubah pengamatan bobot tongkol berkelobot, bobot tongkol tidak berkelobot, panjang tongkol, panjang tongkol berbiji, diameter tongkol, dan baris biji tongkol.

Tabel 5. Rata-rata jumlah daun tanaman jagung berdasarkan dosis pupuk kandang

\begin{tabular}{lccccc}
\hline \multirow{2}{*}{ Dosis Pupuk Kandang $\left(\right.$ ton $\left.^{-1}{ }^{-1}\right)$} & \multicolumn{4}{c}{ Umur Tanaman (MST) } & \multirow{2}{*}{ Pertambahan Jumlah Daun 3-6 MST } \\
\cline { 2 - 5 } & 3 & 4 & 5 & 6 & 5.5 \\
\hline 0 & 5.0 & $7.0 \mathrm{~b}$ & $8.6 \mathrm{c}$ & 10.6 & 6.1 \\
10 & 5.0 & $7.0 \mathrm{~b}$ & $9.3 \mathrm{bc}$ & 10.6 & 6.3 \\
20 & 4.6 & $7.0 \mathrm{~b}$ & $9.6 \mathrm{ab}$ & 11.0 & 5.7 \\
30 & 5.6 & $7.6 \mathrm{a}$ & $10.3 \mathrm{a}$ & 11.0 & \\
\hline
\end{tabular}

Keterangan: Angka yang diikuti huruf berbeda pada kolom yang sama berbeda nyata berdasarkan hasil Duncan's multiple range test (DMRT) pada taraf $\alpha=10 \%$, MST: minggu setelah tanam.

Tabel 6. Rata-rata diameter batang tanaman jagung $(\mathrm{mm})$ berdasarkan dosis pupuk kandang

\begin{tabular}{lccccc}
\hline \multirow{2}{*}{ Dosis Pupuk Kandang $($ ton ha } & -1 \\
& \multicolumn{4}{c}{ Umur Tanaman (MST) } & \multirow{2}{*}{ Pertambahan Diameter Batang 3-6 MST } \\
\cline { 2 - 5 } & 3 & 4 & 5 & 6 & \\
\hline 0 & 11.44 & 15.52 & 19.60 & 25.48 & 14.04 \\
10 & 13.56 & 17.61 & 21.66 & 28.01 & 14.45 \\
20 & 13.15 & 17.25 & 21.34 & 27.82 & 14.67 \\
30 & 12.23 & 17.18 & 22.13 & 28.96 & 16.74 \\
\hline
\end{tabular}

Keterangan: MST: minggu setelah tanam.

Tabel 7. Rata-rata Jumlah tanaman petak bersih, jumlah tongkol petak bersih, bobot tongkol petak bersih, bobot tongkol layak pasar.

\begin{tabular}{|c|c|c|c|c|}
\hline $\begin{array}{l}\text { Dosis Pupuk } \\
\text { Kandang (ton } \mathrm{ha}^{-1} \text { ) }\end{array}$ & $\begin{array}{c}\sum \text { Tanaman } \\
\text { Petak Bersih }\end{array}$ & $\begin{array}{c}\sum \text { Tongkol } \\
\text { Petak Bersih }\end{array}$ & $\begin{array}{l}\text { Bobot Tongkol Petak } \\
\text { Bersih }\left(\mathrm{kg} 2.4 \mathrm{~m}^{-2}\right)\end{array}$ & $\begin{array}{c}\text { Bobot Tongkol Layak } \\
\text { Pasar }\left(\mathrm{kg} 2.4 \mathrm{~m}^{-2}\right)\end{array}$ \\
\hline 0 & 24.3 & 22.3 & 5.27 & 4.37 \\
\hline 10 & 23.6 & 18.6 & 5.54 & 4.76 \\
\hline 20 & 22.0 & 18.0 & 5.46 & 4.63 \\
\hline 30 & 22.3 & 21.0 & 6.26 & 5.51 \\
\hline
\end{tabular}

Tabel 8. Rata-rata bobot tongkol berkelobot, bobot tongkol tidak berkelobot, panjang tongkol, panjang tongkol berbiji, diameter tongkol, baris biji tongkol.

\begin{tabular}{lcccccc}
\hline $\begin{array}{l}\text { Dosis Pupuk } \\
\text { Kandang } \\
\left.\text { (ton ha } \mathrm{h}^{-1}\right)\end{array}$ & $\begin{array}{c}\text { Bobot Tongkol } \\
\text { Berkelobot } \\
(\mathrm{g})\end{array}$ & $\begin{array}{c}\text { Bobot Tongkol } \\
\text { Tidak Berkelobot } \\
(\mathrm{g})\end{array}$ & $\begin{array}{c}\text { Panjang } \\
\text { Tongkol } \\
(\mathrm{cm})\end{array}$ & $\begin{array}{c}\text { Panjang } \\
\text { Tongkol Berbiji } \\
(\mathrm{cm})\end{array}$ & $\begin{array}{c}\text { Diameter } \\
\text { Tongkol } \\
(\mathrm{mm})\end{array}$ & $\begin{array}{c}\text { Baris Biji } \\
\text { Tongkol }\end{array}$ \\
\hline 0 & 278.60 & 225.67 & 18.02 & 15.00 & 47.56 & 15.33 \\
10 & 323.13 & 260.40 & 19.28 & 16.83 & 49.95 & 15.07 \\
20 & 366.80 & 286.80 & 19.82 & 16.84 & 51.16 & 16.40 \\
30 & 379.00 & 287.93 & 20.63 & 18.51 & 50.47 & 15.60 \\
\hline
\end{tabular}


Dosis pupuk kandang tidak menunjukkan pengaruh nyata terhadap skor warna daun dan persentase derajat manis (Tabel 9). Hasil analisis uji klorofil menunjukkan dosis pupuk kandang tidak berpengaruh nyata terhadap peubah pengamatan klorofil $\mathrm{a}$, klorofil $\mathrm{b}$, dan klorofil $\mathrm{a}+\mathrm{b}$ (Tabel 10).

Tabel 9. Rata-rata skor warna daun dan derajat kemanisan

\begin{tabular}{lcc}
\hline $\begin{array}{l}\text { Dosis Pupuk } \\
\text { Kandang (ton ha }\end{array}{ }^{-1}$ ) & $\begin{array}{c}\text { Warna } \\
\text { Daun }\end{array}$ & $\begin{array}{c}\text { Derajat } \\
\text { Kemanisan } \\
\text { (brix) }\end{array}$ \\
\hline 0 & 3.60 & 16.00 \\
10 & 4.07 & 17.33 \\
20 & 4.07 & 15.67 \\
30 & 4.20 & 15.67 \\
\hline
\end{tabular}

Tabel 10. Hasil analisis uji klorofil daun jagung manis

\begin{tabular}{lccc}
\hline $\begin{array}{l}\text { Dosis Pupuk } \\
\text { Kandang } \\
\left(\text { ton ha }^{-1}\right)\end{array}$ & $\begin{array}{c}\text { Klorofil a } \\
(\mathrm{mg} / \mathrm{g})^{*}\end{array}$ & $\begin{array}{c}\text { Klorofil b } \\
(\mathrm{mg} / \mathrm{g})^{*}\end{array}$ & $\begin{array}{c}\text { Klorofil a+b } \\
(\mathrm{mg} / \mathrm{g})^{*}\end{array}$ \\
\hline 0 & 2.17 & 0.72 & 2.89 \\
10 & 2.36 & 0.78 & 3.13 \\
20 & 2.38 & 0.77 & 3.15 \\
30 & 2.06 & 0.68 & 2.73 \\
\hline
\end{tabular}

Keterangan: * per g bobot basah

Penelitian ini menunjukkan bahwa pengaruh perlakuan dosis nyata pada komponen tinggi tanaman dan jumlah daun tanaman jagung. Tinggi tanaman berbeda nyata pada 5 MST dengan perlakuan dosis pupuk 30 ton $\mathrm{ha}^{-1}$ dengan kenaikan tinggi tanaman sebesar $9.04 \%$ dibandingkan dengan tanpa perlakuan dosis pupuk. Perlakuan dosis pupuk kandang 30 ton ha ${ }^{-1}$ berbeda nyata dengan perlakuan tanpa dosis pupuk kandang, dosis 10 , dan 20 ton $\mathrm{ha}^{-1}$ pada karakter tinggi tanaman 5 MST. Hal ini disebabkan karena unsur nitrogen yang terkandung dalam pupuk kandang. Dosis 30 ton $\mathrm{ha}^{-1}$ menyumbang $510 \mathrm{~kg} \mathrm{~N}$ sedangkan dosis rekomendasi dengan pupuk urea $300 \mathrm{~kg}$ menyumbang $138 \mathrm{~kg}$ N. Perbandingan antara dosis pupuk kandang dan urea terpaut jauh, hal ini dikarenakan pupuk kandang, seperti halnya pupuk organik lainnya, tidak mudah tersedia bagi tanaman. Menurut Novizan (2002) nitrogen sangat dibutuhkan pada tahap pertumbuhan tinggi tanaman, nitrogen digunakan tanaman untuk membentuk asam amino yang akan diubah menjadi protein dan dibutuhkan juga untuk membentuk senyawa seperti klorofil, asam nukleat, dan enzim. Tersedianya nitrogen dalam pupuk kandang akan mempercepat pembentukan bagian-bagian vegetatif tanaman karena jaringan meristem yang akan melakukan pembelahan sel, perpanjangan dan pembesaran sel-sel baru, dan protoplasma sehingga pertumbuhan tanaman berlangsung dengan baik (Rosmarkam dan Yuwono, 2002).

Perlakuan dosis pupuk berpengaruh nyata terhadap komponen jumlah daun tanaman jagung pada 4 dan 5 MST. Jumlah daun tertinggi terdapat pada perlakuan dosis pupuk kandang 30 ton $\mathrm{ha}^{-1}$ dengan kenaikan berturut-turut sebesar $8.57 \%$ dan $19.76 \%$ terhadap kontrol. Jumlah daun berbeda nyata pada dosis pupuk 30 ton $\mathrm{ha}^{-1}$ dibandingkan perlakuan tanpa dosis pupuk kandang. Lakitan (2011) mengemukakan bahwa unsur hara yang paling berpengaruh terhadap pertumbuhan dan perkembangan daun adalah unsur $\mathrm{N}$, jumlah daun yang lebih banyak umumnya di sebabkan oleh kandungan unsur $\mathrm{N}$ yang banyak. Myrna (2006) menyatakan bahwa tersedianya unsur nitrogen pada awal pertumbuhan akan mempengaruhi jumlah dan luas daun yang terbentuk, dengan demikian kandungan klorofil yang dihasilkan juga lebih tinggi untuk tanaman mampu menghasilkan karbohidrat /asimilat dalam jumlah yang cukup untuk pertumbuhan vegetatif.

Menurut Anwar dan Sudadi (2013) peranan bahan organik dibedakan menjadi: (1) fungsi fisik, membantu pembentukan struktur tanah dan kadar air yang baik, (2) fungsi kimia, penyumbang sifat aktif koloid tanah, (3) fungsi hara, menyumbang sumber hara, terutama $\mathrm{N}, \mathrm{P}$, dan $\mathrm{S}$ bagi pertumbuhan tanaman, dan (4) fungsi fisiologi baik langsung maupun tidak langsung, hal ini disebabkan karena senyawa-senyawa organik yang dapat berfungsi sebagai hormon tumbuh.

Data analisis usaha tani jagung manis organik per hektar disajikan pada Tabel 11. Usaha tani jagung manis yang dilakukan dari awal sampai dengan panen akan membutuhkan biaya untuk pengadaan sarana produksi, seperti sewa lahan, benih, pupuk, dan tenaga kerja. Analisis usaha tani pada dosis 10 ton $\mathrm{ha}^{-1}$ menunjukkan hasil panen per hektar sebesar Rp. 148750000 , total biaya produksi Rp. 25420 000. Metode yang digunakan untuk mengetahui efisiensi usaha tani jagung adalah dengan menghitung nila R/C Ratio. Menurut Soehardjo (1996) ukuran ekonomi yang umum digunakan untuk menggambarkan kinerja sektor dan komoditas agrobisnis adalah rasio R/C (revenue and cost ratio) yang menunjukkan perbandingan antara penerimaan dan biaya usaha tani. Nilai R/C Ratio yang didapat dari data diatas dapat dikatakan efisien karena lebih dari satu yaitu 4.852. Besarnya pendapatan yang diterima dari analisis usaha tani adalah Rp. 123330000 per hektar. 
Tabel 11. Analisis usaha tani per hektar jagung manis organik dengan 10 ton ha ${ }^{-1}$ pupuk kandang kambing

\begin{tabular}{lccrr}
\hline \multicolumn{1}{c}{ Uraian } & Satuan & Volume & Harga Satuan (Rp) & Total (Rp) \\
\hline A. Jumlah total penerimaan bobot tongkol panen & $\mathrm{Kg}$ & 19.833 & 7500 & 148750000 \\
\hline B. Biaya tunai & & & & \\
$\quad$ 1. Sarana produksi & & & & \\
$\quad$ a. Benih jagung manis & $\mathrm{kg}$ & 8 & 90000 & 720000 \\
$\quad$ b. Pupuk Kandang & $\mathrm{kg}$ & 10000 & 750 & 7500000 \\
2. Tenaga kerja & & & & \\
$\quad$ a. Pengolahan tanah & HKP & 20 & 60000 & 1200000 \\
$\quad$ b. Penanaman & HKP & 10 & 60000 & 600000 \\
$\quad$ c. Pemupukan & HKP & 15 & 60000 & 900000 \\
$\quad$ d. Pemeliharaan & HKP & 60 & 60000 & 3600000 \\
$\quad$ e. Pemanenan & HKP & 15 & 60000 & 900000 \\
$\quad$ 3. Sewa lahan per musim & & & & 100000000 \\
\hline C. Total biaya & & & & 125420000 \\
\hline D. Keuntungan & & & & 430000 \\
\hline E. R/C Ratio
\end{tabular}

\section{KESIMPULAN}

Perlakuan dosis pupuk kandang berpengaruh terhadap pertumbuhan jagung manis organik. Perlakuan dosis pupuk kandang 30 ton $\mathrm{ha}^{-1}$ berpengaruh nyata pada peningkatan tinggi tanaman dan jumlah daun. Perlakuan dosis pupuk kandang tidak berpengaruh nyata terhadap produksi dan komponen produksi jagung manis organik.

\section{DAFTAR PUSTAKA}

Anwar, S., U. Sudadi. 2013. Kimia Tanah, IPB Press, Bogor.

[BMKG] Badan Meteorologi Klimatologi dan Geofisika. Data Iklim Stasiun Dramaga. BMKG. Bogor.

[BPS] Badan Pusat Statistik. 2017. Peningkatan Penduduk Indonesia (Badan Sensus Penduduk). BPS, Jakarta.

[KEMENTAN] 2013. Permentan: Pupuk Organik, Pupuk Hayati dan Pembenah Tanah. KEMENTAN, Jakarta.

Hartatik, W., L.R. Widowati. 2006. Pupuk kandang. Dalam Simanungkalit et al. (ed). Pupuk Organik dan Pupuk Hayati. p.59-82. Balai Besar Litbang Sumberdaya Lahan Pertanian.

Huber, M., E. Rembialkowska, D. Srednicka, S. Bugel, van de Vijver. 2011. Organic food and impact on human health: Assessing the status quo and prospects of research: Review. NJAS - Wageningen Journal of Life Sciences. 58:103-109.

Iskandar, D. 2007. Pengaruh dosis pupuk N, P dan K terhadap pertumbuhan dan produksi tanaman jagung manis di lahan kering. Jurnal Sains dan Teknologi. 30 : 26-34.
Lakitan, B. 2011. Dasar-Dasar Fisiologi Tumbuhan. Raja Grafindo Persada, Jakarta.

Lingga, P., Marsono. 2006.Petunjuk Penggunaan Pupuk. Penebar Swadaya, Jakarta.

MacGillivray, J.H. 1961. Vegetable Production With Special References to Western Crops. McGraw-Hill Book Company, Inc, New York.

Mayrowani, H. 2012. Pengembangan pertanian organik di Indonesia. Forum Penelitian Agro Ekonomi. 30(2): 91-108.

Muljaningsih, S. 2011. Preferensi konsumen dan produsen produk organik di Indonesia. Wacana. 14(4):1-5.

Myrna, N.E.F. 2006. Hasil tanaman jagung pada berbagai dosis dan cara pemupukan $\mathrm{N}$ pada lahan dengan sistem olah tanah minimum. J. Agronomi. 9 (1).

Novizan. 2002. Petunjuk Pemupukan Efektif. Agromedia, Jakarta.

Pranata, A.S. 2010. Meningkatkan Hasil Panen dengan Pupuk Organik. Agromedia Pustaka, Jakarta.

Rosmarkam, A., N.W. Yuwono. 2002. Ilmu Kesuburan Tanah. Kanisius, Yogyakarta.

Seprita, L., Surinah. 2012. Respon tanaman jagung manis akibat pemberian Tiens Golden Harvest. [Skripsi]. Dipublikasikan. Staf Pengajar Fakultas Pertanian Universitas Lancang Kuning Jurusan Agroteknologi.

Soehardjo. 1996. Ilmu Usahatani dan Penelitian untuk Pengembangan Petani Kecil. Penebar Swadaya, Jakarta 